\title{
PENGARUH METODE BERMAIN PERAN MAKRO TERHADAP KEMAMPUAN BERPIKIR SIMBOLIK ANAK KELOMPOK B
}

\author{
Salsabila Arum Zahwa \\ Titin Faridatun Nisa' \\ Yulias Wulani Fajar \\ Program Studi Pendidikan Guru Pendidikan Anak Usia Dini Universitas Trunojoyo Madura \\ email: salsabila.zahwa08@gmail.com
}

Received January 2018, Accepted March 2018, Published April 2018

\begin{abstract}
The Influences of Macro Role Playing Method on Children's Symbolic Thinking Capacity at Group B TK. This research aims to investigate the influence of macro role playing method on the children's symbolic thinking ability at group B, TK Seruni Perumnas Kamal. Symbolic thinking is the ability to use symbols such as numbers, letters and images. This study was focused on examining macro role playing method to stimulate the children on the ability of using symbols. This research utilized quantitative approach by using experimental method with Pre-experimental research design in form of one-group pretest posttest. The subject of this study are 13 children at group B, TK Seruni Perumnas Kamal. Data were collected through observation and documentation. Then, data were analyzed by using wilcoxon level test. The result of data analysis was revealed that $\mathrm{t}_{\text {count }}$ value is 0 and $\mathrm{T}$ table value 17 , as $0<17$, then Ha was accepted. Based on the data analysis, it shows there is a significant influence on macro role playing method on the children's symbolic thinking ability at group B, TK Seruni Perumnas Kamal
\end{abstract}

Keywords : Method of Playing the Role of macro, symbolic thinking, Early Childhood.

\begin{abstract}
Abstrak: Pengaruh Metode Bermain Peran Makro Terhadap Kemampuan Berpikir Simbolik Anak Kelompok B. Tujuan dari penelitian ini untuk mengetahui pengaruh metode bermain peran makro terhadap kemampuan berpikir simbolik anak kelompok B TK Seruni Perumnas Kamal. Berpikir simbolik merupakan kemampuan dalam menggunakan simbol-simbol seperti angka, huruf dan gambar. Berpikir simbolik yang diteliti yaitu dengan metode bermain peran makro untuk menstimulus anak dalam kemampuan menggunakan simbolsimbol. Penelitian ini menggunakan pendekatan kuantitatif dengan menggunakan metode eksperimen dengan desain penelitian Pre-eksperimental Desain jenis one-group pretest posttest. Subjek penelitian ini merupakan anak kelompok B TK Seruni Perumnas Kamal sebanyak 13 anak. Teknik pengumpulan data melalui observasi dan dokumentasi. Teknik analisis data menggunakan uji jenjang wilcoxon. Hasil analisis data diperoleh nilai $\mathrm{T}_{\text {hitung }} 0$ dan nilai $\mathrm{T}_{\text {tabel }}=17$ maka $0<17$ sehingga $H_{a}$ diterima. Berdasarkan analisis data tersebut menunjukkan terdapat pengaruh yang signifikan antara metode bermain peran makro terhadap kemampuan berpikir simbolik anak kelompok B TK Seruni Perumnas Kamal.
\end{abstract}

Kata Kunci : Metode Bermain Peran Makro, Berpikir Simbolik, Anak Usia Dini.

Pendidikan mengandung upaya pembinaan, pengembangan, peningkatkan potensi, serta peningkatan kemampuan yang dimiliki anak untuk mencapai kemajuan dalam hidupnya. Salah satunya adalah Pendidikan Anak Usia Dini yang mengalami perkembangan sangat pesat. Menurut Suyadi (2014:22), pendidikan Anak Usia Dini (PAUD) pada hakikatnya adalah pendidikan yang diselenggarakan dengan tujuan untuk memfasilitasi pertumbuhan dan perkembangan anak secara menyeluruh atau menekankan pada pengembangan seluruh aspek kepribadian anak. Oleh karena itu, PAUD memberi kesempatan bagi anak untuk mengembangkan kepribadian dan potensi secara maksimal. Atas dasar ini, lembaga PAUD perlu menyediakan berbagai kegiatan yang dapat mengembangkan berbagai aspek perkembangan seperti kognitif, bahasa, sosial, emosi, fisik dan motorik.

Penyelenggaraan pendidikan anak usia dini dapat berlangsung secara formal, non formal maupun informal. Sehingga anak memiliki kesiapan yang optimal di dalam memasuki pendidikan dasar dan kesiapan untuk menghadapi kehidupan di masa dewasa. Istilah anak usia dini di Indonesia secara yuridis ditujukan pada 
anak sejak lahir sampai dengan usia enam tahun.

Lebih lanjut pasal 1 ayat 14 Undang-undang Nomor 20 Tahun 2003 tentang Sistem Pendidikan nasional menyatakan bahwa "Pendidikan anak usia dini adalah suatu upaya pembinaan yang ditujukan kepada anak sejak lahir sampai dengan usia enam tahun yang dilakukan melalui pemberian rangsangan pendidikan untuk membantu pertumbuhan dan perkembangan jasmani dan rohani". Selanjutnya, pada pasal 28 tentang Pendidikan anak Usia Dini dinyatakan bahwa "(1) Pendidikan anak usia dini diselenggarakan sebelum jenjang pendidikan dasar, (2) Pendidikan anak usia dini dapat diselenggarakan melalui jalur pendidikan formal, non formal, dan/atau informal, (3) Pendidikan anak usia dini jalur pendidikan formal: TK, RA, atau bentuk lain yang sederajat, (4) Pendidikan anak usia dini jalur pendidikan non-formal: KB, TPA, atau bentuk lain yang sederajat, (5) pendidikan usia dini jalur pendidikan informal: pendidikan keluarga atau pendidikan yang diselenggarakan oleh lingkungan, dan (6) Ketentuan mengenai pendidikan anak usia dini sebagaimana dimaksud dalam ayat (1), ayat (2), ayat (3), dan ayat (4) diatur lebih lanjut dengan peraturan pemerintah." Aspek-aspek yang harus dikembangkan pada anak usia dini menurut Standar Tingkat Pencapaian Perkembangan Anak (STPPA) mengenai aspek perkembangan dan pertumbuhan yang meliputi aspek perkembangan nilai agama dan moral, fisik-motorik, kognitif, bahasa, sosial-emosional, serta seni. Semua aspek ini sama-sama memiliki kepentingan untuk dikembangkan secara optimal, salah satu aspeknya adalah perkembangan kognitif. Menurut Fadlillah (2012:41), perkembangan kognitif merupakan perkembangan yang terkait dengan kemampuan berpikir seseorang. Perkembangan kognitif mempunyai peranan penting bagi keberhasilan anak dalam belajar, karena aktivitas dalam belajar selalu berhubungan dengan masalah mengingat dan berfikir.
Berpikir merupakan suatu aktivitas mental yang dialami oleh seseorang yang dibutuhkan oleh seseorang, khususnya dalam memecahkan masalah dalam kehidupannya. Menurut Ruggierro (dalam Nisa', 2017: 39) mengartikan berpikir sebagai suatu aktivitas mental untuk membantu memformulasikan atau memecahkan suatu masalah, membuat suatu keputusan, atau memenuhi hasrat keingintahuan (fulfill a desire to understand). Hal ini karena karakteristik anak yang memiliki rasa keingintahuan yang tinggi sehingga pada masa ini merangsang perkembangan kemampuan berpikir anak, khususnya perkembangan kognitifnya.

Perkembangan kognitif erat kaitannya dengan perkembangan kemampuan matematika dan pemecahan masalah. Dalam pembelajaran matematika memiliki dua tujuan, sebagaimana menurut Soedjadi (dalam Karim, 2016: 60) bahwa pembelajaran matematika perlu memperhatikan dua tujuan, yaitu yang bersifat formal dan tujuan yang bersifat material. Tujuan formal ini lebih menekankan pada penataan nalar dan pembentukan kepribadian. Sedangkan tujuan yang bersifat material menekankan pada kemampuan memecahkan masalah dan menerapkan matematika. Dengan mengacu pada tujuan tersebut diharapkan perkembangan kognitifnya dapat berkembang secara optimal.

Perkembangan kognitif anak dapat dilihat melalui Standar Tingkat Pencapaian Perkembangan Anak (STPPA). Terdapat beberapa ruang lingkup perkembangan kognitif pada anak usia 3 bulan hingga 6 tahun. Ruang lingkup perkembangan kognitif ada 3 yaitu belajar dan pemecahan masalah, berfikir logis, dan berpikir simbolik. Menurut Diane (2010:325), berpikir simbolik kemampuan mengingat dan berpikir tentang simbol-simbol atau membayangkan secara mental suatu objek yang tidak ada dengan menggunakan simbol, kata, angka atau gambar.

Menurut STPPA berpikir simbolik pada anak usia 5-6 tahun yaitu menyebutkan bilangan 1-10, 
menggunakan lambang bilangan untuk menghitung, mencocokkan bilangan dengan lambang bilangan, mengenal berbagai macam lambang huruf vokal dan konsonan, dan mempresentasikan berbagai macam benda dalam bentuk gambar atau tulisan. Sedangkan menurut Iriani (2016:207), fungsi simbolik merupakan kemampuan individu untuk menggunakan representasi mental atau menggunakan simbol-simbol seperti katakata, angka dan gambar.

$$
\text { Selain ruang lingkup }
$$

perkembangan kognitif perlu adanya metode pembelajaran yang tepat dalam proses pembelajaran. Menurut Fadlillah (2012:163), terdapat beberapa metode pembelajaran anak usia dini yang dapat digunakan yaitu metode ceramah, metode tanya jawab, metode pembiasaan, metode keteladanan, metode bermain, metode demonstrasi, metode bercerita, metode bernyanyi, metode wisata alam, metode pemecahan masalah dan metode simulasi/bermain peran.

Metode bermain peran merupakan salah satu kegiatan bermain aktif yang menyenangkan, dengan bermain peran anak diberi kesempatan untuk mengeksplorasi apa yang ada di lingkungan sekitarnya. Menurut Mutiah (2010:115), bermain peran dapat dibagi menjadi dua yaitu bermain peran mikro dan makro.

Sedangkan
$(2014: 207)$ bermain peran makro merupakan Anak bermain menjadi tokoh menggunakan alat berukuran seperti sesungguhnya yang digunakan anak untuk menciptakan dan memaikan peran. Ada beberapa macam bermain peran makro yang dapat dilakukan pada anak yaitu mengenai profesi seperti dokter, perawat, guru, petani, penjual dan pembeli.

Berdasarkan fakta di lapangan ada beberapa TK yang masih kurang dalam mengenal tentang simbol-simbol angka dan huruf. Berdasarkan observasi dan hasil wawancara lanjutan yang dilakukan peneliti pada tanggal $17 \mathrm{Juli}$ 2017 di TK Seruni Perumnas Kamal, peneliti menemukan permasalahan yang sama pada kegiatan pembelajaran anak kelompok B bahwa ketika proses kegiatan pembelajaran di kelas guru berpedoman pada buku lembar kerja anak (LKA) kurikulum 2013. Kegiatan yang dilakukan anak yaitu menulis, berhitung, dan mewarnai. Dalam kegiatan menulis kemampuan anak masih kurang. Kemampuan anak tersebut bisa dilihat dari kegiatan anak ketika menulis huruf. Anak masih belum mengenal beberapa huruf vokal atau konsonan. Selain menulis anak juga melakukan kegiatan berhitung. Pada saat kegiatan berhitung anak kurang memahami konsep bilangan. Kegiatan tersebut dapat dikatakan sebagai kegiatan mengenal simbol.

Peneliti juga menemukan permasalahan dalam kegiatan bermain peran makro menjadi penjual dan pembeli di kelompok B dengan jumlah 19 anak. Kegiatan yang dilakukan guru yaitu bermain peran makro menjadi penjual dan pembeli. Barang yang akan dijualkan yaitu jajanan khas lapis koci-koci dan kue bolu. Anak-anak membawa baki yang berisi jajanan untuk dijualkan kepada wali murid atau ibu guru lainnya. Anak juga menghitung banyak jajan yang laku dan tidak laku. Selain itu anak juga menuliskan kue yang dibeli oleh pembeli. Hal ini dapat terlihat ketika guru meminta anak mulai melakukan peran, menyuruh anak untuk menyebutkan banyak barang yang dijual, dan mengitung jumlah kue yang dijual. Dari kegiatan tersebut ada beberapa anak yang tidak mengikuti perintah guru, adapula yang tidak mendengarkan guru. Selain menghitung, anak juga menuliskan beragam kue yang akan dijualkan kepada wali murid.

Sehingga dapat diketahui bahwa dari 19 anak ada 13 anak yang belum mampu dalam menyebutkan bilangan 120 dengan tepat, menggunakan lambang bilangan untuk mengitung dan mengenal berbagai macam huruf vokal dan konsonan. Sedangkan 6 anak sudah mampu menyebutkan bilangan 1-20 dengan tepat, mampu menggunakan lambang bilangan untuk menghitung, dan mampu mengenal berbagai lambang huruf vokal dan konsonan dengan tepat. Dalam kegiatan bermain peran menjadi penjual dan pembeli guru menekankan pada perkembangan moral dan bahasa anak. 
Sehingga perkembangan kognitif anak khususnya dalam berpikir simbolik anak masih kurang maksimal.

Berdasarkan uraian diatas maka pemberian metode bermain peran menjadi penjual dan pembeli diharapkan anak mampu memecahkan permasalahan dalam kehidupan sehari-harinya yaitu dalam aspek kognitif terutama berpikir simbolik. Selain itu, anak mampu mengembangkan seluruh potensi yang dimiliki sesuai dengan kemampuannya seoptimal mungkin.

Berdasarkan pada paparan diatas, dengan adanya permasalahan diatas maka peneliti berusaha mengetahui apakah ada pengaruh metode bermain peran makro dengan kemampuan berpikir simbolik anak. Sehingga peneliti mengambil penelitian dengan judul "Pengaruh Metode Bermain Peran Makro Terhadap Kemampuan Berpikir Simbolik Anak Kelompok B Di TK Seruni Perumnas Kamal”.

\section{METODE}

Metode penelitian ini menggunakan pendekatan kuantitatif eksperimen. Menurut Sugiyono (2013:3), metode penelitian eksperimen dapat diartikan sebagai metode penelitian yang digunakan untuk mencari pengaruh perlakuan tertentu terhadap yang lain dalam kondisi yang terkendalikan. Penelitian ini peneliti menggunakan metode eskperimen dengan desain PreEksperimen (pre-experimental designs) dengan jenis One-Group Pretest-Postest Design. Dikatakan pre-experimental design karena desain ekperimen belum merupakan eksperimen yang sungguhsungguh dan masih terdapat variabel luar yang ikut berpengaruh terhadap bentuknya variabel dependen. Jadi, hasil eksperimen yang merupakan variabel dependen itu bukan semata-mata dipengaruhi oleh variabel independen. Penelitian ini menggunakan dengan jenis One-Group Pretest-Posttest Design. Di dalam penelitian ini terdapat pretest dan posttest yang dilakukan untuk mengetahui dan membandingkan kemampuan berpikir simbolik sebelum dan sesudah diberi perlakuan.
Populasi dalam penelitian ini adalah seluruh anak kelompok B di TK Seruni Perumnas Kamal yang berjumlah 19 anak. Sampel pada penelitian ini menggunakan teknik nonprobability sampling, didalam teknik nonprobability sampling terdapat beberapa macam, maka peneliti menggunakan sampling purposive. Jadi sampel yang mewakili dalam penelitian ini yaitu 13 anak. Terdiri dari 7 anak laki-laki dan 6 anak perempuan.

Teknik pengumpulan data yang digunakan peneliti yaitu menggunakan observasi dan dokumentasi. Penelitian ini menggunakan jenis observasi sebagai berikut, jika dilihat dari keterlibatan pengamatan peneliti menggunakan observasi berperanserta (Participant observation) karena peneliti terlibat secara langsung dalam kegiatan seharihari. Dokumentasi yang digunakan peneliti berupa perangkat pembelajaran seperti foto-foto dan video kegiatan belajar anak kelompok B di TK Seruni Perumnas Kamal selama proses pembelajaran berlangsung mulai dari pretest, treatment, dan posttest.

Dilihat dari angka signifikasi yang telah diketahui bahwa $\mathrm{L}_{\text {hitung }}>\mathrm{L}_{\text {tabel }}$ maka analisis data yang akan digunakan peneliti dalam penelitian ini yaitu menggunakan statistik nonparametris dengan teknik analisis data uji dua sampel berpasangan yaitu uji wilcoxon. Teknik analisis data uji dua sampel berpasangan wilcoxon digunakan untuk menguji hipotesis dua sampel yang berpasangan jika data berbentuk ordinal.

Adapun cara pengambilan keputusan pada uji jenjang wilcoxon dengan taraf kesalahan 5\% menurut Sugiyono (2016:136), yaitu sebagai berikut: Jika $T_{\text {hitung }}<T_{\text {tabel }}$, maka hipotesis alternatif $\left(\mathrm{H}_{\mathrm{a}}\right)$ diterima

Jika $\mathrm{T}_{\text {hitung }} \geq \mathrm{T}_{\text {tabel, }}$ maka hipotesis alternatif $\left(\mathrm{H}_{\mathrm{a}}\right)$ ditolak.

\section{HASIL DAN PEMBAHASAN}

Berikut merupakan data dari hasil pretest dan posttest. 
34 Jurnal PG-PAUD Trunojoyo : Jurnal Pendidikan dan Pembelajaran Anak Usia Dini, Volume 5, Nomor 1, April 2018, hal $30-38$

\section{Tabel 1 Hasil Pretest dan Posttes}

\begin{tabular}{|l|l|l|l|l|}
\hline No & Nama & $\begin{array}{l}\text { Pretest } \\
(\mathrm{X})\end{array}$ & $\begin{array}{l}\text { Posttest } \\
(\mathrm{Y})\end{array}$ & Beda \\
\hline 1 & EP & 2,04 & 2,86 & 0,82 \\
\hline 2 & FDS & 1,90 & 3,11 & 1,21 \\
\hline 3 & ASP & 2,07 & 3,22 & 1,15 \\
\hline 4 & AM & 2,00 & 3,18 & 1,18 \\
\hline 5 & AR & 2,11 & 2,90 & 0,79 \\
\hline 6 & ERAR & 1,72 & 2,32 & 0,61 \\
\hline 7 & GFH & 2,33 & 2,93 & 0,61 \\
\hline 8 & KAWP & 2,04 & 3,07 & 1,04 \\
\hline 9 & LDS & 2,14 & 3,11 & 0,97 \\
\hline 10 & LNR & 2,18 & 3,15 & 0,97 \\
\hline 11 & MAR & 2,18 & 2,96 & 0,78 \\
\hline 12 & MZU & 2,11 & 3,18 & 1,07 \\
\hline 13 & MRF & 2,00 & 3,11 & 1,11 \\
\hline
\end{tabular}

Tabel 1 diatas merupakan data hasil pengamatan sebelum perlakuan (pretest) dan sesudah perlakuan (posttest) tentang kemampuan berpikir simbolik anak Kelompok B TK Seruni Kamal. Data yang terkumpul diatas merupakan nilai dari empat indikator berpikir simbolik anak usia 5-6 tahun yaitu menyebutkan lambang bilangan 1-20, menggunakan lambang bilangan untuk menghitung, dan mengenal berbagai macam lambang huruf vokal dan konsonan. Kemampuan berpikir simbolik anak sebelum perlakuan (treatment) menggunakan metode bermain peran makro (jual beli) secara kumulatif terdapat 7 anak yang nilainya tergolong belum berkembang (BB), 6 anak yang tergolong mulai berkembang (MB), tidak ada anak yang tergolong berkembang sesuai harapan (BSH), dan tidak ada anak yang tergolong berkembang sangat baik (BSB). Sedangkan kemampuan berpikir simbolik anak sesudah perlakuan (posttest) menggunakan metode bermain peran makro (jual beli), terdapat 4 anak yang tergolong berkembang sesuai harapan (BSH) dan 9 anak tergolong berkembang sangat baik (BSB).

Uji prasyarat analisis data dalam penelitian ini yaitu bertujuan untuk mengetahui data berdistribusi normal atau tidak berdistribusi normal, peneliti menghitung data dengan uji normalitas data menggunakan rumus Liliefors. Adapun hasil dari uji normalitas data yang telah diperhitungkan oleh peneliti sebagai berikut :

Tabel 2 Hasil Uji Normalitas Liliefors

\begin{tabular}{|l|l|l|l|}
\hline NO & Pretest/Posttest & Lhitung & Ltabel \\
\hline 1. & Pretest & 0,4129 & 0,234 \\
\hline 2. & Posttest & 0,4365 & 0,234 \\
\hline \multicolumn{4}{|c|}{ Berdasarkan hasil dari uji } \\
\hline
\end{tabular}

normalitas yang telah dilakukan oleh peneliti bahwa data berdistribusi tidak normal. Dilihat dari angka signifikasi yang telah diketahui maka analisis data yang akan digunakan peneliti dalam penelitian ini yaitu menggunakan statistik nonparametris dengan teknik analisis data uji dua sampel berpasangan yaitu uji Wilcoxon. Teknik analisis data uji dua sampel berpasangan Wilcoxon digunakan untuk menguji hipotesis dua sampel yang berpasangan jika data berbentuk ordinal. Terbukti bahwa angka signifikasi pretest nilai $\mathrm{T}_{\text {hitung }}=0,4129$ dan nilai $\mathrm{T}_{\text {tabel }}=0,234$, sehingga nilai $T_{\text {hitung }}>T_{\text {tabel }}(0,4129>$ $0,234)$, sedangkan angka signifikasi posttest adalah nilai $\mathrm{T}_{\text {hitung }}=0,4365$ dan nilai $\mathrm{T}_{\text {tabel }}=0,234$, sehingga nilai $\mathrm{T}_{\text {hitung }}>$ $\mathrm{T}_{\text {tabel }}(0,4365>0,234)$.

Hal tersebut memperkuat bahwa data yang telah didapat oleh peneliti telah terbukti data tidak berdistribusi normal. Karena data telah diketahui tidak berdistribusi normal maka tidak memenuhi syarat untuk melakukan uji statistik parametris dan pengujian hipotesis diubah menggunakan uji nonparametris. Penelitian ini menggunakan uji nonparametrik uji jenjang bertanda Wilcoxon. Peneliti menggunakan uji nonparametrik uji jenjang bertanda Wilcoxon karena pada penelitian ini sampel yang diukur sama, dan keseluruhan sampel diberi dua macam perlakuan yaitu Pretest-Posttest dan tidak berdistribusi normal. Adapun hasil dari uji jenjang wilcoxon dapat disajikan dalam tabel 3 sebagai berikut: 
Jurnal PG-PAUD Trunojoyo : Jurnal Pendidikan dan Pembelajaran Anak Usia Dini, Volume 5, Nomor 1, April 2018, hal $30-38$

Tabel 3 Hasil Uji Jenjang Bertanda Wilcoxon

\begin{tabular}{|l|l|l|l|l|l|l|}
\hline \multirow{2}{*}{ Nama } & \multirow{2}{*}{$\begin{array}{c}\text { Pretest } \\
\text { (Xa1) }\end{array}$} & \multirow{2}{*}{$\begin{array}{c}\text { Posttest } \\
(\text { Xb1 })\end{array}$} & $\begin{array}{c}\text { Beda } \\
(\text { Xb1- }\end{array}$ & \multicolumn{4}{|l|}{ Tanda jenjang } & Jenjang & + & - \\
\hline Anak 1 & 2,04 & 2,86 & 0,82 & 5 & +5 & 0 \\
\hline Anak 2 & 1,90 & 3,11 & 1,21 & 13 & +13 & 0 \\
\hline Anak 3 & 2,07 & 3,22 & 1,15 & 11 & +11 & 0 \\
\hline Anak 4 & 2,00 & 3,18 & 1,18 & 12 & +12 & 0 \\
\hline Anak 5 & 2,11 & 2,90 & 0,79 & 4 & +4 & 0 \\
\hline Anak 6 & 1,72 & 2,32 & 0,61 & 1,5 & $+1,5$ & 0 \\
\hline Anak 7 & 2,33 & 2,93 & 0,61 & 1,5 & $+1,5$ & 0 \\
\hline Anak 8 & 2,04 & 3,07 & 1,04 & 8 & +8 & 0 \\
\hline Anak 9 & 2,14 & 3,11 & 0,97 & 6,5 & $+6,5$ & 0 \\
\hline Anak 10 & 2,18 & 3,15 & 0,97 & 6,5 & $+6,5$ & 0 \\
\hline Anak 11 & 2,18 & 2,96 & 0,78 & 3 & +3 & 0 \\
\hline Anak 12 & 2,11 & 3,18 & 1,07 & 9 & +9 & 0 \\
\hline Anak 13 & 2,00 & 3,11 & 1,11 & 10 & +10 & 0 \\
\hline & & & & & T \\
& & & & 91 & 0 \\
\hline
\end{tabular}

Setelah mengetahui nilai $\mathrm{T}_{\text {hitung }}$ kemudian nilai $\mathrm{T}_{\text {hitung }}$ dibandingkan dengan nilai $\mathrm{T}_{\text {tabel. }}$ Nilai $\mathrm{T}_{\text {tabel }}$ merupakan nilai dari tabel kritis dalam uji jenjang bertanda Wilcoxon. Untuk memperoleh hasil yang besar atau signifikan dan mendapatkan kesalahan yang relative kecil, maka dalam penelitian ini signifikansi yang digunakan sebesar 5\%. Subjek dalam penelitian ini berjumlah 13, sehingga nilai $\mathrm{N}=13$. Untuk mendapatkan nilai $\mathrm{T}_{\text {tabel, }}$ dapat dilihat pada tabel kritis dalam uji jenjang bertanda Wilcoxon yang telah terlampir dengan melihat taraf signifikansi $5 \%$ dan nilai $\mathrm{N}=13$. Nilai $\mathrm{T}_{\text {tabel }}$ yang diperoleh dari melihat tabel adalah sebesar 17 .

Berdasarkan hasil perhitungan data pada penelitian ini menggunakan uji jenjang bertanda Wilcoxon, dapat diketahui bahwa nilai $\mathrm{T}_{\text {hitung }} 0$ dan nilai $\mathrm{T}_{\text {tabel }}=17$, sehingga nilai $\mathrm{T}_{\text {hitung }}<\mathrm{T}_{\text {tabel }}(0<$ 17). Hal ini menunjukkan bahwa nilai 0 jauh di bawah 17. Berdasarkan kriteria keputusan pada uji jenjang bertanda wilcoxon yang telah terpapar diatas maka dapat disimpulkan bahwa Ha diterima. Hal ini berarti ada pengaruh antara metode bermain peran makro terhadap kemampuan berpikir simbolik anak kelompok B di TK Seruni Perumnas Kamal.

Kegiatan pada pretest 1 yaitu anak belajar mengenai tanaman bunga. Sebelum kegiatan inti dimulai anak berdoa terlebih dahulu, membacakan pancasila, berhitung 1-20 dan bernyanyi. Saat proses KBM akan dimulai, guru mengulang kembali pembelajaran yang pernah diajarkan pada hari sebelumnya. Kegiatan tersebut mengenai bagianbagian tanaman. Ketika kegiatan berlangsung guru membagikan buku LKA kepada masing-masing anak. Selanjutnya guru meminta anak untuk menyebutkan bagian-bagian tanaman. Setelah itu guru membuat sebuah gambar tanaman bunga di papan tulis dengan menggunakan spidol. Anak membuka buku LKA pada halaman yang telah ditentukan oleh guru. Selain itu guru meminta anak untuk menuliskan bagian bunga yang terdiri dari mahkota, benang sari, kelopak dan tangkai. Anak juga diminta untuk menghitung jumlah mahkota bunga.

Sebelum kegiatan pretest 2 ada beberapa butir penyataan yaitu butir pernyataan satu dari indikator 1 yaitu anak mampu menyebutkan urutan simbol 1-20. Butir pernyataan kedua dari indikator 1 anak mampu menyebutkan simbol 1-20 yang diberi label angka. Butir pernyataan ketiga indikator 2 yaitu anak mampu menyebutkan konsep huruf vokal. Butir pernyataan keempat dari indikator 2 yaitu anak mampu menyebutkan konsep huruf konsonan. Butir pernyataan kelima dari indikator 2 yaitu anak mampu menuliskan nama tanaman, nama anak yang diawali dengan huruf vokal dan konsonan. Butir pernyataan keenam dari indikator 3 yaitu anak mampu menghitung banyak benda. Butir penyataan ketujuh dari indikator 3 yaitu anak mampu menghitung jumlah daun. Hal ini sependapat dengan Diane (2010:236) bahwa simbolik itu merupakan kemampuan untuk menggunakan simbol, kata, angka atau gambar.

Adapun persiapan kegiatan treatment yaitu kegiatan bermain peran makro. kegiatan bermain peran makro untuk mengajarkan anak tentang berpikir simbolik pada anak kelompok B yang merupakan suatu bentuk upaya untuk merubah kemampuan anak dari yang belum mampu terhadap berpikir simbolik anak menjadi mampu terhadap berpikir 
36 Jurnal PG-PAUD Trunojoyo : Jurnal Pendidikan dan Pembelajaran Anak Usia Dini, Volume 5,

Nomor 1, April 2018, hal $30-38$

simbolik. Dalam kegiatan ini telah disesuaikan dengan karakteristik anak usia dini yaitu. Sebelum kegiatan inti dimulai anak berdoa terlebih dahulu, membacakan pancasila, berhitung 1-20 dan bernyanyi. Ketika kegiatan inti dimulai guru menjelaskan terlebih dahulu kegiatan yang akan dilakukan oleh anakanak. Kegiatan tersebut yaitu bermain peran makro, anak berperan menjadi penjual dan pembeli. Saat kegiatan berlangsung guru menjelaskan barang yang akan dijual seperti sayuran (terong, timun dan tomat) dan buah-buahan (mangga dan rambutan).

Kegiatan treatment tersebut digabung dengan kegiatan posttest 1 , sebelum memasuki kegiatan posttest 1 ada beberapa butir penyataan yaitu butir penyataan satu dari indikator 1 yaitu anak mampu menyebutkan urutan simbol 1-20. Butir pernyataan kedua dari indikator 1 anak mampu menyebutkan simbol 1-20 yang diberi label angka. Butir pernyataan ketiga indikator 2 yaitu anak mampu menyebutkan konsep huruf vokal. Butir pernyataan keempat dari indikator 2 yaitu anak mampu menyebutkan konsep huruf konsonan. Butir pernyataan kelima dari indikator 2 yaitu anak mampu menuliskan nama benda yang diawali dengan huruf vokal dan konsonan. Butir pernyataan keenam dari indikator 3 yaitu anak mampu menghitung banyak benda. Butir penyataan ketujuh dari indikator 3 yaitu anak mampu menghitung jumlah uang. Hal ini sependapat dengan Iriani (2016:207), bahwa kemampuan individu untuk menggunakan representasi mental atau menggunakan simbol-simbol seperti kata-kata, angka dan gambar. Setelah dilakukan treatment terdapat peningkatan pada nilai anak. Hal ini sependapat dengan Haenilah (2015:105), bermain peran makro dapat mengembangkan daya fikir dan kemampuan imajinasi sehingga anak dapat menuangkan pengalaman inderanya dalam bermain simbolik. Dari penjelasan diatas dapat dilihat kemampuan kognitif anak dalam berpikir simbolik anak berkembang sangat baik dalam menggunakan simbol-simbol seperti kata-kata, angka dan gambar.
Kegiatan posttest 2 yaitu guru membagi anak menjadi 2 kelompok, setiap kelompok terdiri dari 3 anak untuk menjadi seorang penjual dan sisanya menjadi seorang pembeli. Seorang anak berperan sebagai penjual sayur dan penjual buah. Kegiatan pada postest 2 terdapat perbedaan. Perbedaan tersebut yaitu pada saat kegiatan posttest 1 anak yang berperan menjadi penjual dan pembeli bertukar posisi. Sehingga anak bisa merasakan semua yang berperan menjadi penjual dan pembeli. Kegiatan tersebut disesuaikan dengan tema.

Setelah dilakukan treatment terdapat peningkatan pada nilai anak. Hal ini sependapat dengan Hamalik ketika anak sudah mampu bermain peran makro, berarti anak sudah menunjukkan kemampuan kognitif yang cukup baik, karena bermain peran makro membutuhkan banyak sekali keterampilan baik 4 itu bahasa, rasa percaya diri, kreatifitas, daya cipta, inisiatif, keberanian, kerjasama, dan kejujuran. Hal ini sependapat dengan Iriani (2016:207) bahwa kemampuan kognitif anak dalam berpikir simbolik anak berkembang sangat baik dalam menggunakan simbolsimbol seperti kata-kata, angka dan gambar.

Selanjutnya memasuki dalam kegiatan bermain peran makro, anak mulai menjajakan jualannya kepada pembeli. Berbagai macam buah dan sayur yang akan dijual. Berbagai macam sayuran dan buah-buahan yang akan dijual seperti sawi, buncis, apel dan salak. Dalam kegiatan tersebut anak satu-persatu membeli sayur maupun buah dengan membawa uang mainan. Nilai mata uang tersebut yaitu Rp1.000, Rp2.000, Rp5.000, dan Rp10.000. Anak juga menghitung banyak barang yang laku terjual dan tidak laku terjual. Selain itu anak mengitung jumlah uang. Kegiatan yang dilakukan anak merupakan kegiatan jual beli. Menurut Bergen (2014:3), pada permainan jual-beli anak akan diajarkan untuk melakukan transaksi jual-beli menggunakan uang secara benar sehingga diharapkan mampu mengembangkan kemampuan kognitif pada anak usia dini. 
Berdasarkan hasil penelitian dan beberapa teori diatas, dapat menjawab rumusan masalah bahwa ada pengaruh metode bermain peran makro terhadap kemampuan berpikir simbolik pada anak kelompok B. Selain berdasarkan paparan di atas dapat juga dibuktikan dari hasil perhitungan yang telah dilakukan peneliti dan dapat diketahui bahwa hipotesis $H_{0}$ ditolak dan hipotesis alternatif $H_{a}$ diterima Hal ini berarti terdapat perbedaan yang signifikan antara sebelum pemberian perlakuan kegiatan bermain peran makro terhadap kemampuan berpikir simbolik pada anak kelompok B.

\section{SIMPULAN}

Berdasarkan hasil perhitungan yang dilakukan oleh peneliti pada penelitian ini menggunakan uji jenjang bertanda Wilcoxon, dapat diketahui bahwa nilai $\mathrm{T}_{\text {hitung }}$ yang berjumlah 0 lebih kecil dari kriteria keputusan yang telah ditetapkan oleh peneliti. Angka $T_{\text {hitung yang diperoleh yaitu } 0 \text { dan }}$ dibandingkan dengan nilai kriteria keputusan yaitu $T_{\text {tabel }}=17$. Sehingga dapat disimpulkan bahwa nilai $T_{\text {hitung }}=$ 0 jauh lebih kecil dibandingkan dengan nilai $T_{\text {tabel }}=17$. Jika $T_{\text {hitung }}<T_{\text {tabel }}$ yaitu $0<17$. Hal ini menunjukkan bahwa nilai 0 jauh dibawah 17 , maka diterima yang artinya terdapat pengaruh yang signifikan antara metode bermain peran makro terhadap kemampuan berpikir simbolik pada anak kelompok B.

\section{SARAN}

Berdasarkan uraian hasil penelitian yang telah dipaparkan maka disampaikan saran sebagai berikut:

1. Bagi guru

Sebaiknya guru memaksimalkan penggunaan metode pembelajaran di sekolah dan disesuaikan dengan tujuan pembelajaran yang ingin dicapai.

2. Bagi peneliti selanjutnya

Penelitian ini diharapkan dapat bermanfaat untuk penelitian selanjutnya dengan segmen yang berbeda terkait dengan metode bermain peran makro terhadap berpikir simbolik anak. Seperti metode bermain peran makro terhadap penguasaan kosakata dan metode bermain peran makro terhadap kepercayaan diri anak.

\section{DAFTAR PUSTAKA}

Aguswara, W. (2014). "Pengaruh Bermain Peran Jual-Beli Terhadap Kemampuan Mengenal Bilangan Dan Lambang Bilangan Anak Kelompok A Di Tk Tulus Sejati”. Jurnal Ilmu Pendidikan. (Online), Vol.3/No.3/2014. (http://jurnal mahasiswa.unesa.ac.id/article/1073 8/19/article.pdf), diakses 14 Februari 2017.

Fadlillah, M. (2012). Desain Pembelajaran PAUD. Jogjakarta: Ar-Ruzz Media.

Haenilah. (2015). Kurikulum dan Pembelajaran PAUD. Yogyakarta: Media Akademi.

Hapsari, I. (2016). Psikologi Perkembangan Anak. Jakarta: Indeks.

Khumaira, dkk. (2015). "Pengaruh Metode Bermain Peran Makro Terhadap Aspek Perkembangan Berbahasa Anak Usia 5-6 Tahun". Jurnal Pendidikan Anak. (Online),Vol.1/No.5/2015, (http://jurnal.fkip.unila.ac.id/index.p hp/PAUD/article/view/10158), diakses 14 Februari 2017.

Latif, M. (2013). Orientasi Baru Pendidikan Anak Usia Dini. Jakarta: PT Fajar Interpratama Madiri

Mutiah, D. (2010). Psikologi Bermain Anak Usia dini. Jakarta: Kencana Prenada Media Group.

Nisa', T. F. dan Karim, M. B. (2017). THINK DIFFERENT. Teori dan Praktik dalam Pembelajaran Matematika Anak Usia Dini. Surabaya: Pustaka Idea. 
38 Jurnal PG-PAUD Trunojoyo : Jurnal Pendidikan dan Pembelajaran Anak Usia Dini, Volume 5, Nomor 1, April 2018, hal $30-38$

Karim., M. B. dkk. (2016). Implementasi Islamic Math Character : Paradigma Baru dalam Pembelajaran Matematika. (Online). Jurnal Review Pembelajaran Matematika (JRPM). Vol. 1 (1), 57 - 70. http://jrpm.uinsby.ac.id/index.php/j rpm/article/view/10/pdf, diakses 22 Oktober 2017.

Peraturan Menteri Pendidikan dan Kebudayaan Republik Indonesia Nomer 146 tahun 2014 tentang Struktur Kurikulum PAUD 2013.

Risma R., dkk. (2015). "Pengaruh Kegiatan Bermain Peran Makro Terhadap Aspek Perkembangan Sosial Emosional". Jurnal Pendidikan Anak. (Online),Vol.1/No.1/2015.(http://jurn al.fkip.unila.ac.id/index.php/PAUD/a rticle/view/8444), diakses 15 Februari 2017.

Sugiyono. (2013). Metode Penelitian Pendidikan Pendekatan Kuantitatif, Kualitatif, dan $R \& D$. Bandung: Alfabeta.

Sugiyono. (2016). Statistika Untuk Penelitian. Bandung: Alfabeta.

Suyadi, M. (2013). Konsep Dasar Paud. Bandung: PT Remaja Rosdakarya.

Suyadi. (2014). Teori Pembelajaran Anak Usia Dini. Bandung: PT Remaja Rosdakarya. 